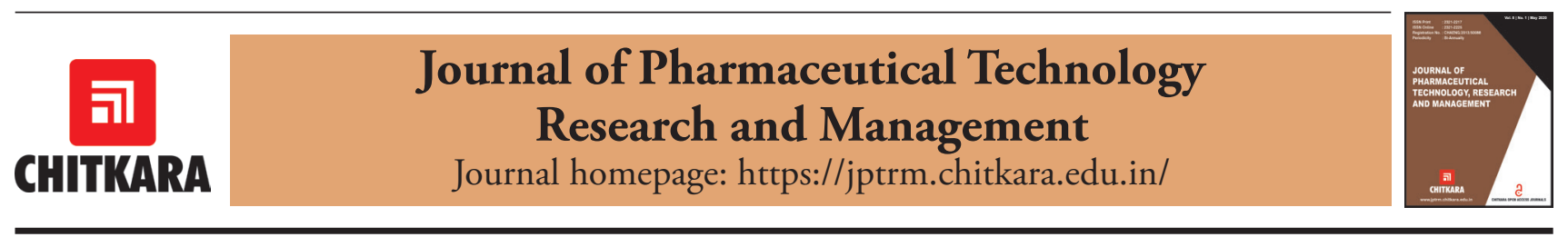

\title{
Phytoalexins: Sources and Their Pharmacological Potential
}

\author{
Bhavika Arora ${ }^{1}$, Rakesh K Sindhu ${ }^{2 *}$ (i) and Sandeep Arora ${ }^{3}$ \\ Chitkara College of Pharmacy, Chitkara University, Punjab-140401, India \\ 'bhavikaarora111@gmail.com \\ ${ }^{3}$ sandeep.arora@chitkara.edu.in \\ 2*rakesh.sindhu@chitkara.edu.in (Corresponding Author)
}

\section{ARTICLE INFORMATION}

Received: December 17, 2019

Revised: February 04, 2020

Accepted: March 02, 2020

Published Online: May 20, 2020

Keywords:

Phytoalexins, Resveratrol, Anti-Diabetic,

Anti-Cancer, Cardio-Protective, Neuro-Protective

DOI: $10.15415 /$ jptrm.2020.81001

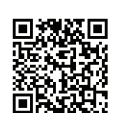

\section{ABSTRACT}

Background: Plants are easily prone towards microbial infections on exposure to microorganisms and pathogens. In order to defense, plants produce low molecular weight secondary metabolites which were later known as "Phytoalexins". These molecules have vast therapeutic potential also. Purpose: The purpose of this review is to explore the phytoalexins and their pharmacological effects. Methods: The data included from the articles were published from Web of Science, PubMed, Medline, Scopus, and Embase by using relevant keywords including plants possessing phytoalexins and their specific biological applications.

Results: The review insights the potential of phytoalexins in various diseases and to explore phytoalexins applications in human health and disease control.

Conclusions: On the basis of this review it may be concluded that phytoalexins have tremendous potential in the treatment and prevention of various life-threatening diseases like diabetes mellitus, cancer, brain damage, and heart attack.

\section{Introduction}

Plants utilizes a complex defense mechanism against pest and pathogens, which lead to the production of low molecular weight secondary metabolites. These metabolites have antimicrobial property and are known as Phytoalexins (Egbuonu et al., 2018). Once the microorganism invaded in the plant, the plant in response to the pathogen release the antimicrobial compounds known as phytoalexins in the infected sites. The biosynthesis of most of the phytoalexins is due to the induction of biotic and abiotic stress (Pedras et al., 2007).

The phytoalexins are not only activated in response to the microbial infection, but they can also be activated by abiotic stresses such as elicitation of UV-light, chemical mediators such as surfactants, antibiotics, plant regulators, heavy metal ions, or the chemical products released by the microorganisms.

Phytoalexins contributed to the various pharmacological activities like antioxidant, anticancer, and cardiovascular activities. The biological activities of phytoalexins are enormous, this give a key idea to biologists and researchers to research on the potential of phytoalexins against various diseases (Grayer, 2001; Bavaresco, 2003; Pedras et al., 2006).

\section{History of Phytoalexins}

The concept of plant phytoalexins was introduced before 70 years ago from the Solanum tuberosum i.e. potato tuber tissue that had been infected by Phytophthora infestans. It was supposed that the tuber tissue, in response produced some chemicals now known as phytoalexins, that inhibited the growth of microorganism and protected the plant against later infections. Muller \& Borger first presented the paper on this hypothesis and later on they experimented on another plants and demonstrated that plants produce such antimicrobial compounds when infected by pathogens (Hammerschmidt, 1999).

\section{Phytoalexins from Different Plant Families}

Phytoalexins are synthesized by variety of plants families like Fabaceae, Solanaceae, Vitaceae, Brassicaceae, Poaceae. Diverse chemically active phytoalexins belong to various families, including terpenoids, phenolics, furanoacetylenes, steroid glycoalkaloids, indoles. The chemical diversity of phytoalexins, their plant family source are summarized in (Table 1) (Suman, 2017). 
<smiles>COC(=O)NCc1c[nH]c2ccccc12</smiles><smiles>O=C1c2ccccc2OCC1c1ccccc1</smiles><smiles>COc1cc(O)cc(/C=C/c2ccc(O)cc2)c1</smiles>

Table 1: Phytoalexins from Different Plant Families.

\begin{tabular}{|c|c|c|c|}
\hline $\begin{array}{l}\text { S. } \\
\text { NO. }\end{array}$ & $\begin{array}{l}\text { PLANT } \\
\text { FAMILY }\end{array}$ & PHYTOALEXINS & REFERENCE \\
\hline 1. & Amaryllidaceae & Flavans & $\begin{array}{l}\text { (Coxon et al., } \\
1980)\end{array}$ \\
\hline 2. & Apiaceae & $\begin{array}{l}\text { Falcarinol, } \\
\text { Xanthotoxin, } \\
\text { 6-methoxymellein }\end{array}$ & $\begin{array}{l}\text { (Kello et al., } \\
\text { 2014) }\end{array}$ \\
\hline 3. & Brassicaceae & $\begin{array}{l}\text { Camalexin, } \\
\text { Brassinin, } \\
\text { spirobrassinin, } \\
\text { brassilexin, } \\
\text { rutalexin }\end{array}$ & $\begin{array}{l}\text { (Browne, } \\
1991)\end{array}$ \\
\hline 4. & Chenopodiaceae & $\begin{array}{l}\text { Safynol, Betagarin, } \\
\text { Betavulgarin }\end{array}$ & $\begin{array}{l}\text { (Geigert et al., } \\
\text { 1973) }\end{array}$ \\
\hline 5. & Euphobiaceae & Casbene & (Sitton, 1975) \\
\hline 6. & Leguminosae & $\begin{array}{l}\text { Isoflavones, } \\
\text { isoflavanones, } \\
\text { coumestants }\end{array}$ & $\begin{array}{l}\text { (Jeandet et al., } \\
\text { 2013) }\end{array}$ \\
\hline 7. & Malvaceae & $\begin{array}{l}\text { Terpenoids, } \\
\text { gossypol }\end{array}$ & $\begin{array}{l}\text { (Lozano et al., } \\
2014 \text { ) }\end{array}$ \\
\hline 8. & Orchidaceae & Loroglossol & (Smith, 2014) \\
\hline 9. & Poaceae & $\begin{array}{l}\text { Sakuranetin, } \\
\text { phytocassanes, } \\
\text { phenylamides, } \\
\text { apigeninidin, } \\
\text { zealexins, } \\
\text { kauralexins }\end{array}$ & $\begin{array}{l}\text { (Jeandet et al., } \\
\text { 2013) }\end{array}$ \\
\hline 10. & Solanaceae & $\begin{array}{l}\text { Capsidiol, } \\
\text { scopoletin }\end{array}$ & $\begin{array}{l}\text { (Jeandet et al., } \\
\text { 2013) }\end{array}$ \\
\hline 11. & Vitaceae & $\begin{array}{l}\text { Resveratrol, } \\
\text { viniferins, piceids, } \\
\text { pterostilbene }\end{array}$ & $\begin{array}{l}\text { (Langcake, } \\
1976)\end{array}$ \\
\hline
\end{tabular}

\section{Phytoalexin Enriched Foods}

From last 10 years, functional foods have developed their place in the market because they are beneficial to human health, and are being used to prevent lifestyle disorders such as cancer, diabetes, obesity, and various cardiac disorders. Phytoalexins were researched many years ago as secondary metabolites with antimicrobial activity synthesised by plants to protect plants from various pathogenic infections. Recently, phytoalexins were investigated in various plant derived foods to provide nutrition and various health benefits. As phytoalexins were explored in showing various activities like anti-inflammatory, anti-diabetic, and even anticancer activity also, so by consuming such phytoalexins rich foods, it is expected to prevent and treat such diseases. Some of phytoalexins with their sources are showed below.

Table 2: Phytoalexins and their Natural food Sources (Boue et al., 2009).

\begin{tabular}{|l|l|}
\hline PHYTOALEXIN & NATURAL FOOD SOURCES \\
\hline Flavonoids & $\begin{array}{l}\text { Nuts, whole grains, citrus fruits, } \\
\text { apples, berries }\end{array}$ \\
\hline Isoflavones & $\begin{array}{l}\text { Soya foods, legumes including } \\
\text { chickpeas, fava beans, pistachios, } \\
\text { peanuts }\end{array}$ \\
\hline Resveratrol & $\begin{array}{l}\text { Peanuts, pistachios, grapes, red and } \\
\text { white wine, blueberries, cranberries }\end{array}$ \\
\hline Brassinin & $\begin{array}{l}\text { Chinese cabbage, Brussels sprouts, } \\
\text { and cauliflower }\end{array}$ \\
\hline Pterostilbene & $\begin{array}{l}\text { Almonds, blueberries, grape leaves, } \\
\text { pterocarpus marsupium heartwood }\end{array}$ \\
\hline Capsidiol & $\begin{array}{l}\text { Orange bell pepper, red bell pepper, } \\
\text { green vegetables }\end{array}$ \\
\hline Sakuranetin & $\begin{array}{l}\text { Cherries, plum, wild carrots, } \\
\text { blackcurrants, black walnuts, } \\
\text { walnuts }\end{array}$ \\
\hline
\end{tabular}

\section{Pharmacological Potential of Phytoalexins}

\subsection{Potential of Phytoalexins in Treatment of Diabetes Mellitus and its Complications}

Diabetes mellitus is a chronic disease which is characterized by hyperglycemia, and a most studied and prevalent disease 
in the whole world. The pathophysiology behind the disease involved insufficientsecretion of insulin orinsulin resistanceor both. From reduction in glucose transporters, to the down regulation in the number of insulin receptors, the process leads to long term damage of various organs like eyes, kidneys, heart and blood vessels ad cause diabetic complications.

A naturally occurring phytoalexin, resveratrol which is found in tea, wine cereals, fruits, vegetables shows potential of acting as an anti-diabetic agent. Based on research and in-vivo studies resveratrol was found to be an effective agent to lower glucose level in both type- 1 and type- 2 diabetes (Huang et al., 2020).

According to, the information from the clinical trials, the phytoalexin improves the insulin resistance on oral administration of single dose and regular dose for months. One of the mechanism behind that is, the resveratrol activates the sirtuin in beta cells which decreases the level of uncoupling protein- 2 called $\mathrm{Ul}$ insulin reCP2 and overcomes the insulin resistance. Moreover, it also stimulates the glucose uptake seven in the absence of insulin via increasing the GLUT4 receptors in the plasma membrane. Cytokines damages the pancreatic beta cells which are insulin releasers, inhibition of cytokines by resveratrol preserve the beta cells and reduce the unnecessarily release of insulin (Öztürk et al., 2017).

\section{Diabetic Neuropathy}

Neuropathy is the complication of both type- 1 and type2 diabetes which results into pain, decrease in movement, and amputation. Induction of oxidative stress in neurons of diabetic patient activates various biochemical pathways and causes damage. Activation of NF- $\kappa \mathrm{B}$ a transcription factor by oxidative stress leads to the production of inflammatory mediators such as cytokines, TNF- $\alpha$, interleukins, COX-2 which shows nerve damage. Resveratrol acts by inhibiting the transcription factors which leads to the down regulation of inflammatory factors and improves the neuropathic pain in diabetic patients (Kumar, 2007; Sharma, 2007).

\section{Diabetic Nephropathy}

Diabetic nephropathy is the major cause of kidney damage and is defined by increase in urinary albumin excretion and affect both type- 1 and type- 2 diabetic patients. The complications show effects like glomerular hypertrophy, proteinuria, reduced glomerular filtration, and lastly impaired renal function.

The results of preclinical studies shows that resveratrol decreases albumin concentration in urine, improves creatinine clearance, and reduce the size of glomerular basement membrane and hence effective against diabetic nephropathy (Wen et al., 2013; Kim et al., 2012).

\section{Diabetic Retinopathy}

It is one of the major prevalent diabetic complication affecting 150 million people worldwide. If not treated properly the complication can lead to retina damage and vision loss. The complication occurs due to inflammation, oxidative stress and lipid peroxidation. One of the study gives results that by administering resveratrol at a dose of $5 \mathrm{mg} / \mathrm{kg}$ for 4 months decreases the blood sugar level as well as reduces the thickness of retina and treat the complication effectively. Another research study by Zeng et al. on rat models at a dose of 5 and $10 \mathrm{mg} / \mathrm{kg}$ for period of 7 months also gave positive results by inhibiting the apoptosis in retina cells induced by higher glucose levels in diabetic patients (Soufi et al., 2012).

\section{Diabetic Liver Damage}

The main pathology behind the complication is liver fibrosis, inflammation of liver called steatohepatitis, and infiltration of intrahepatic fatty tissue. The improper treatment can lead this complication to liver cirrhosis or liver cancer. The recent study gave results that by administering 20 or $40 \mathrm{mg} / \mathrm{kg}$ of resveratrol orally inhibits the activation of NF- $\mathrm{kB}$ pathway and other inflammatory mediators, which results in the low chances of liver damage. Moreover, another study shows that resveratrol in $10 \mathrm{mg} / \mathrm{kg}$ dose for 15 days reduces both blood glucose level and chances of liver damage by reducing the oxidative stress (Hamadi et al., 2012).

\subsection{Potential of Phytoalexins in Treatment of Various Types of Cancer}

According to the data, cancer is seeming to be a threat and a worldwide killer. It accounts for about $23 \%$ of the total deaths in USA and is the second most common disease after cardiac diseases. Cancer is the abnormal growth of cells which is caused by both internal and environmental factors like diet, stress, etc.

The phytoalexins like resveratrol, and others shows the anti-cancer effects and can be used in the cancer therapy. The phytoalexins inhibit the $S$ and $G_{2}$ phase of cell cycle and efficiently causes apoptosis in many types of cancer like leukemia, colon cancer, prostate cancer and breast cancer (Rauf et al., 2018).

\section{Anticancer Potential of Phytoalexins in:}

\section{Skin Cancer}

Brassinin, an indole phytoalexin which was first found as a main constituent of cabbage has been shown to have 
anticancer properties. Later, it was synthesised and found to be effective against the cancer. The phytoalexin was effective against the skin tumor. The activity was observed in 90 day study when the agent was injected in the mice and gave positive results without any side effects and toxicity. The mechanism of action of brassinin is unclear but the unique structural characteristics of the compound of having indole nucleus and isothiocyanate-based side chain, gives great anticancer activity (Mehta, 1995).

\section{Breast Cancer}

It is the major health problem in women in both developing and developed countries. There are more than one million breast cancer cases diagnosed each year. Resveratrol inhibits the breast cancer by various mechanisms such as it decreases the release of anti-apoptotic proteins like $\mathrm{NF \kappa B}$, it suppresses the cell growth by inducing apoptosis. Moreover, it decreases the gene expression of BCL-xl in HER-2 receptor positive and negative breast cancer cell lines (Abdel-Latif, 2015).

\section{Stomach Cancer}

In order to treat stomach cancer, the phytolexin (resveratrol) lowers the mRNA expression of BCL-2, stimulates cytochrome $\mathrm{C}$ and caspase oxidase activities, and causes cell cycle arrest in $G_{0} / G_{1}$ phase (Mohapatra et al., 2014).

\section{Brain Cancer}

Brain cancer is found to be a untreated problem from years. The number of patients of brain tumour have reached 43,800 per year in US. Currently 12,690 patients have died due to this disease. Resveratrol which is effective against many cancer, is also used in the therapy of brain cancer. The phytoalexin crosses the blood brain barrier and reduces the oxidative stress, inflammation and induces apoptosis. Moreover, resveratrol also activates p53, NF- B, Wnt, m-TOR etc. to influence the cancer cell death. Now, resveratrol is used as clinical therapy and saving lives of cancer patients effectively (Riles, 2006).

\section{Lung Cancer}

Lung cancer incidents are now increasing worldwide. Exposure to dust particles or respiratory diseases can lead to this highly prevalent disease. The phytoalexins are found to be effective against lung cancer as they work by various mechanisms, it suppresses the XRCC1 gene and also shows synergistic effect with etoposide (Kiskova, 2020). It aslo inhibits blocks the proliferation of $\mathrm{H} 838$ and $\mathrm{H} 520$ cells. It also inhibits the endothelial growth factor and AKT/ m-TOR mediated pathways (Wang et al., 2015).

\subsection{Potential of Phytoalexin in Treatment of Neurodegenerative Diseases}

Neurons are the building blocks of the nervous system. The degeneration and ageing of neurons due to any of mechanism whether increase in oxidative stress or other lead to death of nerve cells and cause various diseases like alzheimer's, parkinson's disease, huntington's disease and many more (Chen et al., 2015).

\section{Potential of Phytoalexins in Brain Damage}

The preclinical studies gave results that administration of phytoalexin intraperitoneally improves the motor and cognitive impairement and reduces the nerve cell death and damage. Therefore, can be beneficial in the treatment of many CNS disorders marked by nerve cell damage. For example, it showed positive results in treatment of seizures induced by ferric chloride, kainic acid etc. Phytoalexins also shows antioxidant properties as resveratrol protects nerve cells by activating the sirtuin proteins (Pallàs et al., 2009).

\begin{abstract}
Alzheimer's Disease
Alzheimer's disease also called dementia is a progressive neurodegenerative disease as it damages the memory and cognitive functioning. The formation of $\beta$-amyloid plaques is the main pathogenesis behind it. The resveratrol is involved in the degradation and inhibition of polymerization of peptide by activating the proteasome. It also act by increasing the free radical scavenger glutathione and decrease the activity of acetylcholinesterase enzyme. As inflammation also contributes to this disease, so activation of SIRT1 (sirutin1) and inhibition of inflammatory mediators by resveratrol give positive results in the treatment of the disease (Pallàs et al., 2009; Chen et al., 2015).
\end{abstract}

\section{Parkinson's Disease}

It is neurodegenerative disease characterized by nerve cell damage and causes low levels of dopamine, showing symptoms like stiffness, tremors and rigidity in movement. According to various in-vitro and preclinical studies it was concluded that resveratrol shows positive results in the treatment by activating proteins SIRT1 and SIRT2 as the activation shows antioxidant effects (Rocha-González, Ambriz-Tututi \& Granados-Soto, 2008).

\section{Epilepsy}

It is a CNS neurodegenerative disease caused by nerve cell damage and disturbance leading to episodes of unusual behavior called as seizures or convulsions. Just like other anti-seizure drugs resveratrol also acts by inhibiting the 
high voltage $\mathrm{Na}^{+}$channels and shows anticonvulsant action (Chen et al., 2015).

\section{Huntington's Disease}

It is the inherited CNS condition in which the nerve cells break down resulting into symptoms like depression, loss in concentration, mood swings and aggressive behavior. Resveratrol acts bas antioxidant, protects the nerve cell damage by activating sirutin proteins SIRT1 and SIRT2. The results of preclinical studies on rats showed that administration of resveratrol in dose of $5-10 \mathrm{mg} / \mathrm{kg}$ improves the motor movement and cognitive impairment (Rocha-González, Ambriz-Tututi \& Granados-Soto, 2008).

\section{Conclusion}

Plants are prone to diseases, in response to that they release chemicals known as phytoalexins or antimicrobial compouns. Phytoalexins, synthesised by plants in response to pathogenic diseases and microbial infections, show great importance in human health. They contribute in the treatment and prevention of various life threatening diseases like diabetes mellitus, cancer, brain damage, and heart attack. The phytoalexins treat most of the diseases because of having anti-inflammatory and anti-oxidative properties. Decrease in oxidative stress leads to the management and control of diseases. Thus, the review holds the current applications of phytoalexin in human health and diseases.

\section{Acknowledgements}

The authors are grateful to Dr. Madhu Chitkara, Pro Chancellor, Chitkara University, Rajpura, Patiala, India and Dr. Ashok Chitkara, Chancellor, Chitkara University, Rajpura, Patiala, India, for support and institutional facilities.

\section{Authorship Contribution}

Bhavika Arora: Data Collection;

Rakesh K Sindhu: Manuscript Design and evaluation;

Sandeep Arora: Manuscript evaluation.

\section{Conflict of Interest}

The authors declare no conflict of interest, financial or otherwise.

\section{References}

Abdel-Latif, G.A., Al-Abd, A.M., Tadros, M.G., Al-Abbasi, F.A., Khalifa, A.E., \& Abdel-Naim, A.B. (2015). The chemomodulatory effects of resveratrol and didox on herceptin cytotoxicity in breast cancer cell lines. Scientific reports, 5, 12054.

https://doi.org/10.1038/srep12054

Aktaş, H.S., Ozel, Y., Ahmad, S., Pençe, H.H., AyazAdakul, B., Kudas, I., Tetik, S., Sekerler, T., CanbeyGoret, C., Kabasakal, L., \& Elcioglu, H.K. (2019). Protective effects of resveratrol on hepatic ischemia reperfusion injury in streptozotocin-induced diabetic rats. Molecular and Cellular Biochemistry, 460(1-2), 217-224. https://doi.org/10.1007/s11010-019-03582-z

Bavaresco, L.U.I.G.I. (2003). Role of viticultural factors on stilbene concentrations of grapes and wine. Drugs Under Experimental and Clinical Research, 29(5-6), 181-187.

Boue, S.M., Cleveland, T.E., Carter-Wientjes, C., Shih, B.Y., Bhatnagar, D., McLachlan, J.M., \& Burow, M.E. (2009). Phytoalexin-enriched functional foods. Journal of Agricultural and Food Chemistry, 57(7), 2614-2622. https://doi.org/10.1021/jf8040403

Browne, L.M., Conn, K.L., Ayert, W.A., \& Tewari, J.P. (1991). The camalexins: new phytoalexins produced in the leaves of Camelina sativa (Cruciferae). Tetrahedron, 47(24), 3909-3914.

https://doi.org/10.1016/S0040-4020(01)86431-0

Coxon, D.T., O’Neill, T.M., Mansfield, J.W., \& Porter, A.E.A. (1980). Identification of three hydroxyflavan phytoalexins from daffodil bulbs. Phytochemistry, 19(5), 889-891. https://doi.org/10.1016/0031-9422(80)85132-6

Egbuonu, A.C.C., \& Eneogwe, J.C. (2018). Phytoalexins: Current and possible future applications in human health and diseases control. International Journal of Molecular Biology: Open Access, 3(3), 107-112. https://doi.org/10.15406/ijmboa.2018.03.00061

Geigert, J., Stermitz, F.R., Johnson, G., Maag, D.D., \& Johnson, D.K. (1973). Two phytoalexins from sugarbeet (Beta vulgaris) leaves. Tetrahedron, 29(18), 2703-2706. https://doi.org/10.1016/S0040-4020(01)93389-7

Grayer, R.J., \& Kokubun, T. (2001). Plant-fungal interactions: the search for phytoalexins and other antifungal compounds from higher plants. Phytochemistry, 56(3), 253-263. https://doi.org/10.1016/S0031-9422(00)00450-7

Hammerschmidt, R. (1999). Phytoalexins: what have we learned after 60 years? Annual Review of Phytopathology, 37(1), 285-306.

https://doi.org/10.1146/annurev.phyto.37.1.285

Hamadi, N., Mansour, A., Hassan, M.H., Khalifi-Touhami, F., \& Badary, O. (2012). Ameliorative effects of resveratrol on liver injury in streptozotocin-induced 
diabetic rats. Journal of Biochemical and Molecular Toxicology, 26(10), 384-392.

https://doi.org/10.1002/jbt.21432

Huang, D.-D., Shi, G., Jiang, Y., Yao, C., \& Zhu, C. (2020). A review on the potential of Resveratrol in prevention and therapy of diabetes and diabetic complications. Biomedicine \& Pharmacotherapy, 125, 109767. https://doi.org/10.1016/j.biopha.2019.109767

Jeandet, P., Clément, C., Courot, E., \& Cordelier, S. (2013). Modulation of phytoalexin biosynthesis in engineered plants for disease resistance. International Journal of Molecular Sciences, 14(7), 14136-14170. https://doi.org/10.3390/ijms140714136

Jeandet, P., Hébrard, C., Deville, M.-A., Cordelier, S., Dorey, S., Aziz, A., \& Crouzet, J. (2014). Deciphering the role of phytoalexins in plant-microorganism interactions and human health. Molecules, 19(11), 18033-18056. https://doi.org/10.3390/molecules191118033

Jing, Y., Zhaoyang, R., \& Jing, C. (2005). A Promising Secondary Metabolite-Resveratrol [J]. Chinese Agricultural Science Bulletin, 7.

Kello, M., Drutovic, D., Chripkova, M., Pilatova, M., Budovska, M., Kulikova, L., Urdzik, P., \& Mojzis, J. (2014). ROS-dependent antiproliferative effect of brassinin derivative homobrassinin in human colorectal cancer Caco2 cells. Molecules, 19(8), 1087710897. https://doi.org/10.3390/molecules 190810877

Kim, Y.H., Kim, Y.S., Roh, G.S., Choi, W.S., \& Cho, G.J. (2012). Resveratrol blocks diabetes-induced early vascular lesions and vascular endothelial growth factor induction in mouse retinas. Acta Ophthalmologica, 90(1), e31-e37.

https://doi.org/10.1111/j.1755-3768.2011.02243.x

Kiskova, T., Kubatka, P., Büsselberg, D., \& Kassayova, M. (2020). The Plant-Derived Compound Resveratrol in Brain Cancer: A Review. Biomolecules, 10(1), 161. https://doi.org/10.3390/biom10010161

Ko, J.-C., Syu, J.-J., Chen, J.-C., Wang, T.-J., Chang, P.Y., Chen, C.-Y., Jian, Y.-T., Jian, Y.-J., \& Lin, Y.W. (2015). Resveratrol Enhances Etoposide-Induced Cytotoxicity through Down-Regulating ERK 1/2 and AKT-Mediated X-ray Repair Cross-Complement Group 1 (XRCC 1) Protein Expression in Human Non-Small-Cell Lung Cancer Cells. Basic \& Clinical Pharmacology \& Toxicology, 117(6), 383-391.

https://doi.org/10.1111/bcpt.12425

Kumar, A., Kaundal, R.K., Iyer, S., \& Sharma, S.S. (2007). Effects of resveratrol on nerve functions, oxidative stress and DNA fragmentation in experimental diabetic neuropathy. Life Sciences, 80(13), 1236-1244. https://doi.org/10.1016/j.lfs.2006.12.036
Langcake, P., \& Pryce, R.J. (1976). The production of resveratrol by Vitis vinifera and other members of the Vitaceae as a response to infection or injury. Physiological Plant Pathology, 9(1), 77-86. https://doi.org/10.1016/0048-4059(76)90077-1

Lozano-Mena, G., Sánchez-González, M., Juan, M.E., \& Planas, J.M. (2014). Maslinic acid, a natural phytoalexin-type triterpene from olives-a promising nutraceutical? Molecules, 19(8), 11538-11559. https://doi.org/10.3390/molecules190811538

Ma, L., Li, W., Wang, R., Nan, Y., Wang, Q., Liu, W., \& Jin, F. (2015). Resveratrol enhanced anticancer effects of cisplatin on non-small cell lung cancer cell lines by inducing mitochondrial dysfunction and cell apoptosis. International Journal of Oncology, 47(4), 1460-1468. https://doi.org/10.3892/ijo.2015.3124

Mehta, R.G., Liu, J., Constantinou, A., Thomas, C. F., Hawthorne, M., You, M., Gerhauser, C., Pezzuto, J.M., Moon, R.C., \& Moriarty, R.M. (1995). Cancer chemopreventive activity of brassinin, a phytoalexin from cabbage. Carcinogenesis, 16(2), 399-404. https://doi.org/10.1093/carcin/16.2.399

Mohapatra, P., Satapathy, S.R., Das, D., Siddharth, S., Choudhuri, T., \& Kundu, C. N. (2014). Resveratrol mediated cell death in cigarette smoke transformed breast epithelial cells is through induction of p21Waf1/ Cip1 and inhibition of long patch base excision repair pathway. Toxicology and Applied Pharmacology, 275(3), 221-231. https://doi.org/10.1016/j.taap.2014.01.011

Öztürk, E., Arslan, A.K.K., Yerer, M.B., \& Bishayee, A. (2017). Resveratrol and diabetes: A critical review of clinical studies. Biomedicine \& Pharmacotherapy, 95, 230-234. https://doi.org/10.1016/j.biopha.2017.08.070

Pallàs, M., Casadesús, G., Smith, M.A., Coto-Montes, A., Pelegri, C., Vilaplana, J., \& Camins, A. (2009). Resveratrol and neurodegenerative diseases: Activation of SIRT1 as the potential pathway towards neuroprotection. Current Neurovascular Research, 6(1), 70-81. https://doi.org/10.2174/156720209787466019

Pedras, M.S.C., Zheng, Q.-A., \& Sarma-Mamillapalle, V.K. (2007). The phytoalexins from Brassicaceae: structure, biological activity, synthesis and biosynthesis. Natural Product Communications, 2(3), 319-330. https://doi.org/10.1177/1934578X0700200315

Pedras, M.S.C., Adio, A.M., Suchy, M., Okinyo, D.P.O., Zheng, Q.A., Jha, M., \& Sarwar, M.G. (2006). Detection, characterization and identification of crucifer phytoalexins using high-performance liquid chromatography with diode array detection and 
electrospray ionization mass spectrometry. Journal of Chromatography A, 1133(1-2), 172-183. https://doi.org/10.1016/j.chroma.2006.08.015

Rauf, A., Imran, M., Butt, M.S., Nadeem, M., Peters, D.G., \& Mubarak, M.S. (2018). Resveratrol as an anticancer agent: A review. Critical Reviews in Food Science and Nutrition, 58(9), 1428-1447. https://doi.org/10.1080/10408398.2016.1263597

Riles, W.L., Erickson, J., Nayyar, S., Atten, M.J., Attar, B.M., \& Holian, O. (2006). Resveratrol engages selective apoptotic signals in gastric adenocarcinoma cells. World Journal of Gastroenterology, 12(35), 56285634. https://doi.org/10.3748/wjg.v12.i35.5628

Rocha-González, H.I., Ambriz-Tututi, M., \& GranadosSoto, V. (2008). Resveratrol: A natural compound with pharmacological potential in neurodegenerative diseases. CNS Neuroscience \& Therapeutics, 14(3), 234247. https://doi.org/10.1111/j.1755-5949.2008.00045.x

Sen, S. (2017). Role of Phytoalexins in Plant-Microbe Interactions and Human Health. International Journal of Scientific Research and Management, 5(7), 62156225. https://doi.org/10.18535/ijsrm/v5i7.52

Sharma, S., Kulkarni, S.K., \& Chopra, K. (2007). Effect of resveratrol, a polyphenolic phytoalexin, on thermal hyperalgesia in a mouse model of diabetic neuropathic pain. Fundamental \& Clinical Pharmacology, 21(1), $89-94$. https://doi.org/10.1111/j.1472-8206.2006.00455.x

Sitton, D., \& West, C.A. (1975). Casbene: An anti-fungal diterpene produced in cell-free extracts of Ricinus communis seedlings. Phytochemistry, 14(9), 19211925.

https://doi.org/10.1016/0031-9422(75)83098-6
Smith, B., Randle, D., Mezencev, R., Thomas, L., Hinton, C., \& Odero-Marah, V. (2014). Camalexin-induced apoptosis in prostate cancer cells involves alterations of expression and activity of lysosomal protease cathepsin D. Molecules, 19(4), 3988-4005. https://doi.org/10.3390/molecules 19043988

Soufi, F.G., Mohammad-nejad, D., \& Ahmadieh, H. (2012). Resveratrol improves diabetic retinopathy possibly through oxidative stress-Nuclear factor kb-Apoptosis pathway. Pharmacological Reports, 64(6), 1505-1514. https://doi.org/10.1016/S1734-1140(12)70948-9

Sunilkumar, G., Campbell, L.M., Puckhaber, L., Stipanovic, R.D., \& Rathore, K.S. (2006). Engineering cottonseed for use in human nutrition by tissue-specific reduction of toxic gossypol. Proceedings of the National Academy of Sciences, 103(48), 18054-18059. https://doi.org/10.1073/pnas.0605389103

Ward, E.W.B., Unwin, C.H., \& Stoessel, A. (1975). Loroglossol: An orchid phytoalexin. Phytopathology, 65, 632-633.

Wen, D., Huang, X., Zhang, M., Zhang, L., Chen, J., Gu, Y., \& Hao, C.-M. (2013). Resveratrol attenuates diabetic nephropathy via modulating angiogenesis. PloS one, 8(12), e82336. https://doi.org/10.1371/journal.pone.0082336

Zheng, G.H., \& Li, H.Q. (2008). Effects of garlic oil combined with resveratrol on inducing apoptosis and expression of Fas, bcl-2 and bax in human gastric cancer cell line. Zhonghua yu Fang yi xue za zhi [Chinese Journal of Preventive Medicine], 42(1), 39-42. 
司

\section{Journal of Pharmaceutical Technology, Research and Management}

CHITKARA

Chitkara University, Saraswati Kendra, SCO 160-161, Sector 9-C, Chandigarh, 160009, India

Volume 8, Issue 1

May 2020

ISSN 2321-2217

Copyright: [ $(2020$ Bhavika Arora, Rakesh K Sindhu and Sandeep Arora] This is an Open Access article published in Journal of Pharmaceutical Technology, Research and Management (J. Pharm. Tech. Res. Management) by Chitkara University Publications. It is published with a Creative Commons Attribution- CC-BY 4.0 International License. This license permits unrestricted use, distribution, and reproduction in any medium, provided the original author and source are credited. 